Nevada

Environmental

Restoration

Project

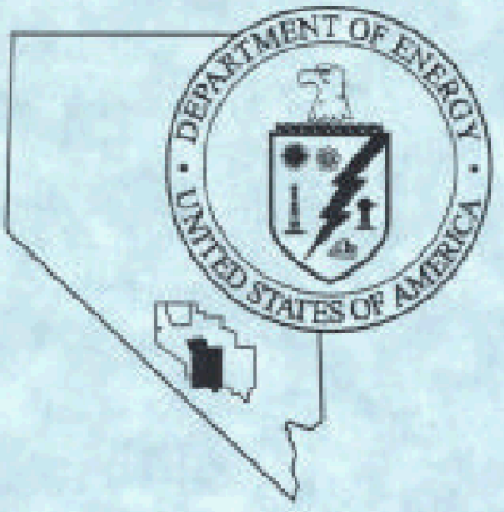

\title{
Corrective Action Plan For Corrective Action Unit 342: Area 23 Mercury Fire Training Pit, Nevada Test Site, Nevada
}

Controlled Copy Number: _

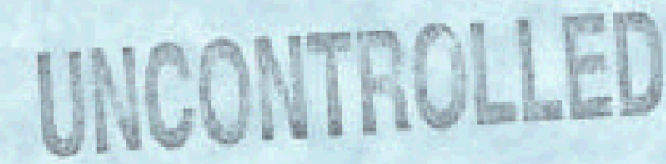

Revision: 0

August 1999

Distribution A - Approved for public release; further dissemination unlimited.

Environmental Restoration

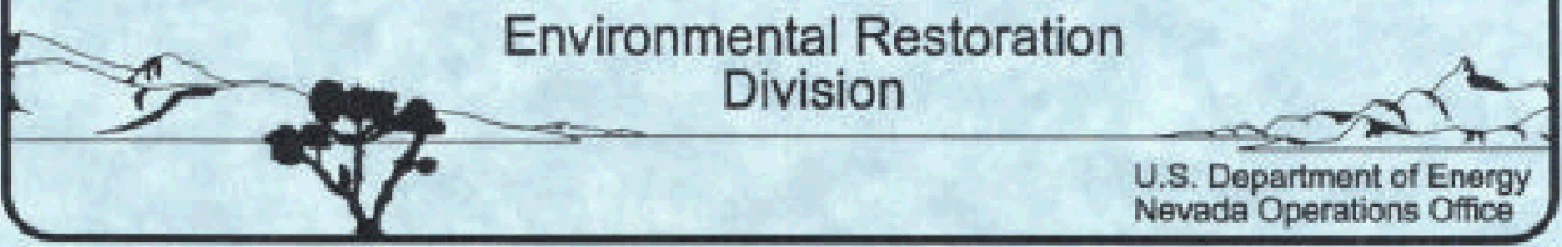


Available to the public from:

U.S. Department of Commerce

National Technical Information Service

5285 Port Royal Road

Springficld, VA 22161-0002

(703) $487-4650$

Available electronically at http://www,doegor/bridge. Available to U.S. Department of Energy and its contractors in paper from.

U.S. Department of Energy

Office of Scientific and Technical Infornation

P.O. Box 62

Oak Ridge, TN 37831-0062

(423) 576-8401

Reference herein to any specific commercial product, process, or service by trade name, trademark, manufacturer, or otherwise, does not necessarily constitute or imply its endorsement, recommendation, or favoring by the U.S. Government or any agency thereof or its contractors or subcontractors. 


\section{CORRECTIVE ACTION PLAN FOR CORRECTIVE ACTION UNIT 342: AREA 23 MERCURY FIRE TRAINING PIT, NEVADA TEST SITE, NEVADA}

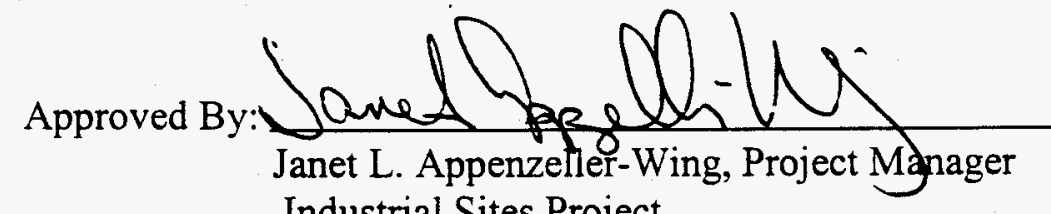
Industrial Sites Project

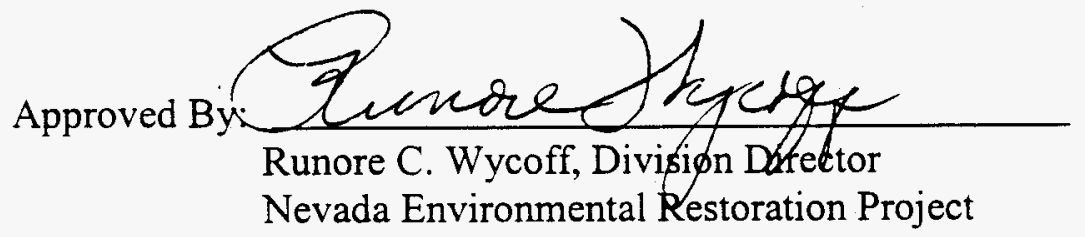

Date: $8 / 26 / 99$ Date: $8 / 26 / 99$ 


\section{TABLE OF CONTENTS}

FIGURES $\ldots \ldots \ldots \ldots \ldots \ldots \ldots \ldots \ldots \ldots \ldots \ldots \ldots \ldots \ldots \ldots \ldots \ldots \ldots \ldots \ldots \ldots \ldots \ldots$

TABLES $\ldots \ldots \ldots \ldots \ldots \ldots \ldots \ldots \ldots \ldots \ldots \ldots \ldots \ldots \ldots \ldots \ldots \ldots \ldots \ldots$ vi

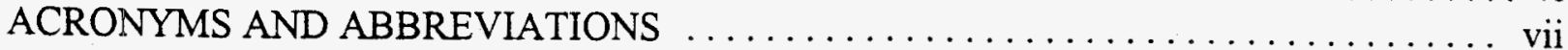

EXECUTIVE SUMMARY $\ldots \ldots \ldots \ldots \ldots \ldots \ldots \ldots \ldots \ldots \ldots \ldots \ldots \ldots \ldots \ldots$

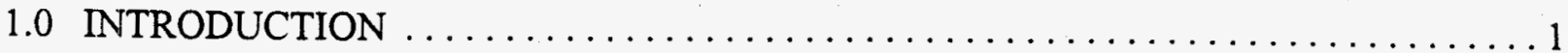

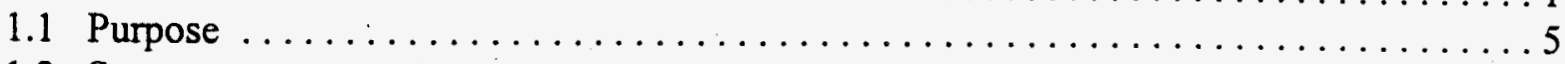

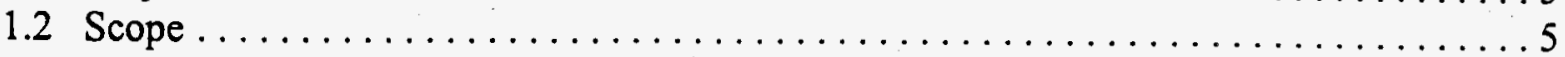

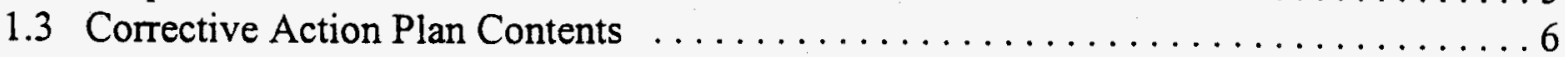

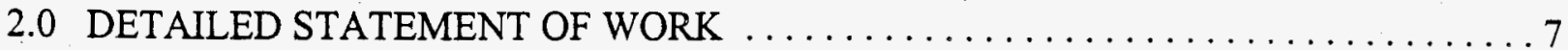

2.1 Approved Alternative Implementation $\ldots \ldots \ldots \ldots \ldots \ldots \ldots \ldots \ldots \ldots \ldots \ldots$

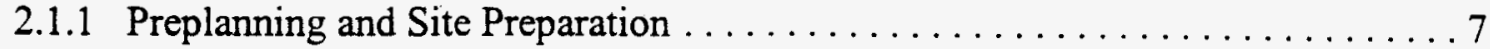

2.1.1.1 Site-Specific Health and Safety Plan/Hazard Analysis . . . . . . . . . . 7

2.1.1.2 Field Management Plan . . . . . . . . . . . . . . . . . . 8

2.1.1.3 National Environmental Policy Act Documentation . . . . . . . . . 8

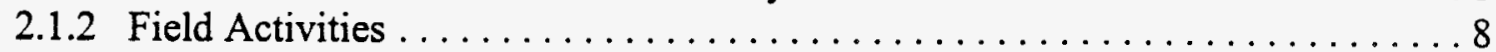

2.1.2.1 Excavation of the Impacted Soil $\ldots \ldots \ldots \ldots \ldots \ldots \ldots \ldots \ldots$

2.1.2.2 Decontamination of Equipment $\ldots \ldots \ldots \ldots \ldots \ldots \ldots \ldots \ldots$

2.1.2.3 Backfilling of Excavated Areas . . . . . . . . . . . . . . . . . 9

2.1.2.4 Grading of Site . . . . . . . . . . . . . . . . . . . . . 9

2.1.2.5 Installation of Soil Gas Vapor Monitoring Well $\ldots \ldots \ldots \ldots \ldots \ldots$

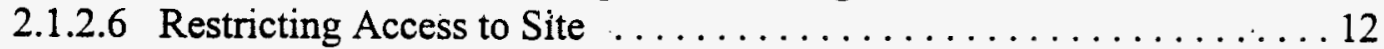

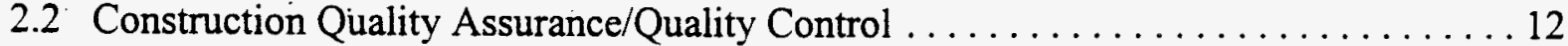

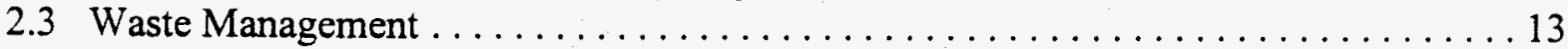

2.3.1 Waste Minimization . . . . . . . . . . . . . . . . . . . . . . . . 13

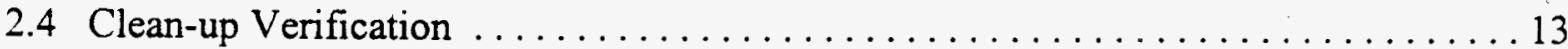

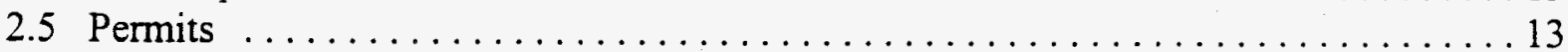

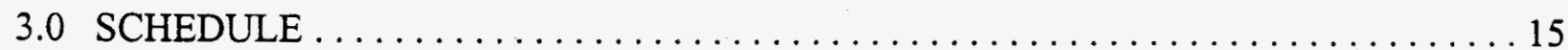

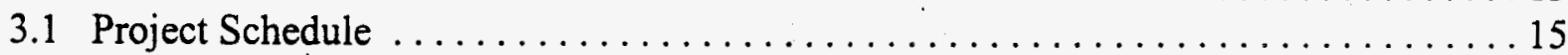

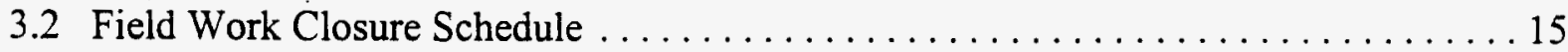

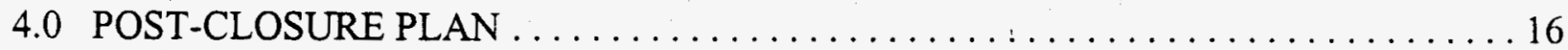

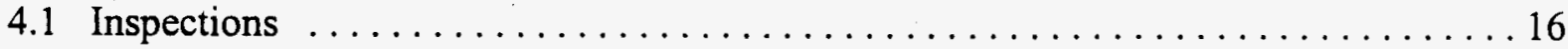

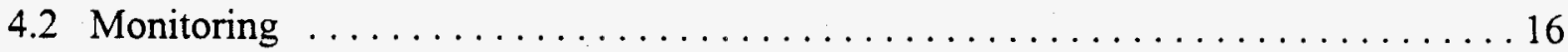

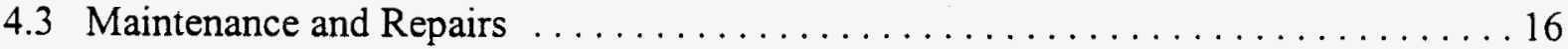

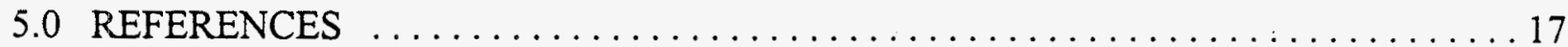




\section{TABLE OF CONTENTS (continued)}

\section{APPENDICES}

Appendix A: Post-Closure Inspection Checklist

Appendix B: Project Organization

Distribution List

\section{FIGURES}

Figure 1 - Location of Mercury Fire Training Pit, Area 23 , Nevada Test Site . . . . . . . . 2

Figure 2 -Proposed Site Layout Plan for the Mercury Fire Training Pit Field Work ....... 3

Figure 3 - Potential Soil Gas Vapor Monitoring Well Designs $\ldots \ldots \ldots \ldots \ldots \ldots \ldots \ldots \ldots 1$

\section{TABLES}

Table 1 - Management of Various Waste Types to Be Produced at the Mercury Fire Training Pit 


\section{ACRONYMS AND ABBREVIATIONS}

\begin{tabular}{|c|c|}
\hline AST & Above Ground Storage Tank \\
\hline $\mathrm{BN}$ & Bechtel Nevada \\
\hline CADD & Corrective Action Decision Document \\
\hline CAIP & Corrective Action Investigation Plan \\
\hline CAU & Corrective Action Unit \\
\hline $\mathrm{cm}$ & centimeter \\
\hline DOE & U.S. Department of Energy \\
\hline $\mathrm{DOE} / \mathrm{NV}$ & U.S. Department of Energy, Nevada Operations Office \\
\hline FFACO & Federal Facility Agreement and Consent Order \\
\hline $\mathrm{ft}$ & foot \\
\hline gal & gallon \\
\hline HA & Hazard Analysis \\
\hline in & inch \\
\hline $\mathrm{L}$ & liter \\
\hline $\mathrm{m}$ & meter \\
\hline $\mathrm{mg}$ & milligram \\
\hline $\mathrm{mg} / \mathrm{kg}$ & milligrams per kilogram \\
\hline NAC & Nevada Administrative Code \\
\hline NDEP & Nevada Division of Environmental Protection \\
\hline
\end{tabular}


NTS

PHA

PVC

SSHASP

SVOC

VOC
Nevada Test Site

Preliminary Hazard Analysis

Polyvinyl Chloride

Site-Specific Health and Safety Plan

Semivolatile Organic Compound

Volatile Organic Compound 


\section{EXECUTIVE SUMMARY}

The Mercury Fire Training Pit is a former fire training area located in Area 23 of the Nevada Test Site (NTS). The Mercury Fire Training Pit was used from approximately 1965 to the early 1990 s to train firefighting personnel at the NTS, and encompasses an area approximately 107 meters (m) (350 feet [ft]) by $137 \mathrm{~m}(450 \mathrm{ft})$. The Mercury Fire Training Pit formerly included a bermed burn pit with four small burn tanks, four large above ground storage tanks (ASTs), an overturned bus, a telephone pole storage area, and areas for burning sheds, pallets, and cables.

During the active life of the Mercury Fire Training Pit, training events were conducted at least monthly and sometimes as often as weekly. Fuels burned during these events included offspecification or rust-contaminated gasoline, diesel, and aviation fuel (JP-4). Other items burned during these events included paint, tires, a pond liner, wood, paper, cloth, and copper cable.

Based on the results of analyses reported in the site characterization report, the only constituent of concern at the Mercury Fire Training Pit is petroleum hydrocarbons. In the AST area, impacted soil was found in shallow soils downslope of the ASTs and at greater depths immediately beneath the ASTs. The maximum petroleum hydrocarbon concentration was 18,000 milligrams per kilograms $(\mathrm{mg} / \mathrm{kg})$ diesel at a depth of $7.6 \mathrm{~m}(25 \mathrm{ft})$ below ground surface. The maximum concentration of petroleum hydrocarbons in the shallow soil (upper $1.5 \mathrm{~m}[5 \mathrm{ft}]$ ) was $2,800 \mathrm{mg} / \mathrm{kg}$ diesel at $1.2 \mathrm{~m}(4 \mathrm{ft})$ below ground surface.

Within the bermed area, the maximum petroleum hydrocarbon concentrations were $10,000 \mathrm{mg} / \mathrm{kg}$ of diesel at $6 \mathrm{~m}(20 \mathrm{ft})$, and $10,000 \mathrm{mg} / \mathrm{kg}$ of an unknown petroleum hydrocarbon at $3 \mathrm{~m}(10 \mathrm{ft})$ below ground surface. Downslope of the burn pit, impacted soil was found in the shallow soils with a maximum concentration of petroleum hydrocarbon of $4,100 \mathrm{mg} / \mathrm{kg}$ diesel at a depth of $0.3 \mathrm{~m}(1 \mathrm{ft})$ below ground surface.

Petroleum hydrocarbons were also fourd in three small areas associated with the overturned bus, the telephone pole storage area, and a burn shed. The maximum petroleum hydrocarbon concentrations at these sites were $1,400 \mathrm{mg} / \mathrm{kg}$ of waste oil, $440 \mathrm{mg} / \mathrm{kg}$ of an unknown hydrocarbon, and $130 \mathrm{mg} / \mathrm{kg}$ of an unknown hydrocarbon, respectively. All concentrations were identified at a depth of $0.3 \mathrm{~m}$ [1 $\mathrm{ft}]$ ) below ground surface, but at different locations.

Closure activities will include excavation of the impacted soil in the aboveground storage tank and burn pit areas to a depth of $1.5 \mathrm{~m}(5 \mathrm{ft})$, and excavation of the impacted surface soil downgradient of the former ASTs and burn pit areas to a depth of $0.3 \mathrm{~m}(1 \mathrm{ft})$. Excavated soil . will be disposed in the Area 6 Hydrocarbon Landfill at the NTS.

The excavated areas will be backfilled with clean borrow soil and the site will be graded to prevent ponding and promote surface drainage. A soil gas vapor monitoring well will be installed and sampled every two years to demonstrate that natural attenuation is degrading the remaining petroleum hydrocarbons on-site. 


\subsection{INTRODUCTION}

The Mercury Fire Training Pit is a former fire training area located in Area 23 of the Nevada Test Site (NTS) (Figure 1). The site is listed as Corrective Action Unit (CAU) 342 and Corrective Action Site 23-56-01 in the Federal Facility Agreement and Consent Order (FFACO, 1996). The Mercury Fire Training Pit was used from approximately 1965 to the early 1990 s to train firefighting and emergency response personnel at the NTS, and encompasses an area approximately 107 meters $(\mathrm{m})(350$ feet [ft]) by $137 \mathrm{~m}(450 \mathrm{ft})$. A site plan of the Mercury Fire Training Pit is shown in Figure 2.

According to the Corrective Action Investigation Plan (CAIP) (U.S. Department of Energy [DOE], 1998a), the Mercury Fire Training Pit formerly included a bermed burn pit with four small burn tanks; four large above ground storage tanks (ASTs); an overturned bus; a telephone pole storage area; and several areas for burning sheds, pallets, and cables.

During the active life of the Mercury Fire Training Pit, training events were conducted at least monthly and sometimes as often as weekly. Fuels burned during these events included offspecification or rust-contaminated gasoline, diesel, and aviation fuel (JP-4). Other items burned during these events included paint, tires, a pond liner, wood, paper, cloth, and copper cable (DOE, 1998a).

Approximately 570 liters (L) (150 gallons [gal]) of fuel were used for each training event resulting in an approximate total of $136,000 \mathrm{~L}(36,000 \mathrm{gal})$ of fuel used over the life of the Mercury Fire Training Pit (DOE, 1998a). Unburned fuel was allowed to pool on the ground and was left to eventually volatilize or soak into the soil. In addition, fuels from the ASTs and fuels and fluids from the overturned bus leaked or spilled onto the ground. Approximately $19 \mathrm{~L}$ to $38 \mathrm{~L}$ (5 gal to $10 \mathrm{gal}$ ) of paint were also burned monthly until sometime in the $1970 \mathrm{~s}$.

Interim actions were taken at the site in 1997 and 1998. These actions included the sampling and removal of the liquids in the ASTs, and steam-cleaning of the tanks. The telephone poles stored on the site were also sampled during this time. All of the tanks, a bus, wooden shed, and other surface debris were removed from the site for salvage or disposal, as applicable.

Site characterization was performed in three phases between September 1997 and June 1998. The first phase took place from September 1997 to April 1998, and involved the removal and characterization of surface debris described previously. The second phase was a passive soil gas survey in December 1997. The results of the first two phases were reported in the CAIP (DOE, 1998a). The third phase included the collection of surface and near-surface soil samples during May and June 1998, and the results were reported in the Corrective Action Decision Document (CADD) (DOE, 1999). 


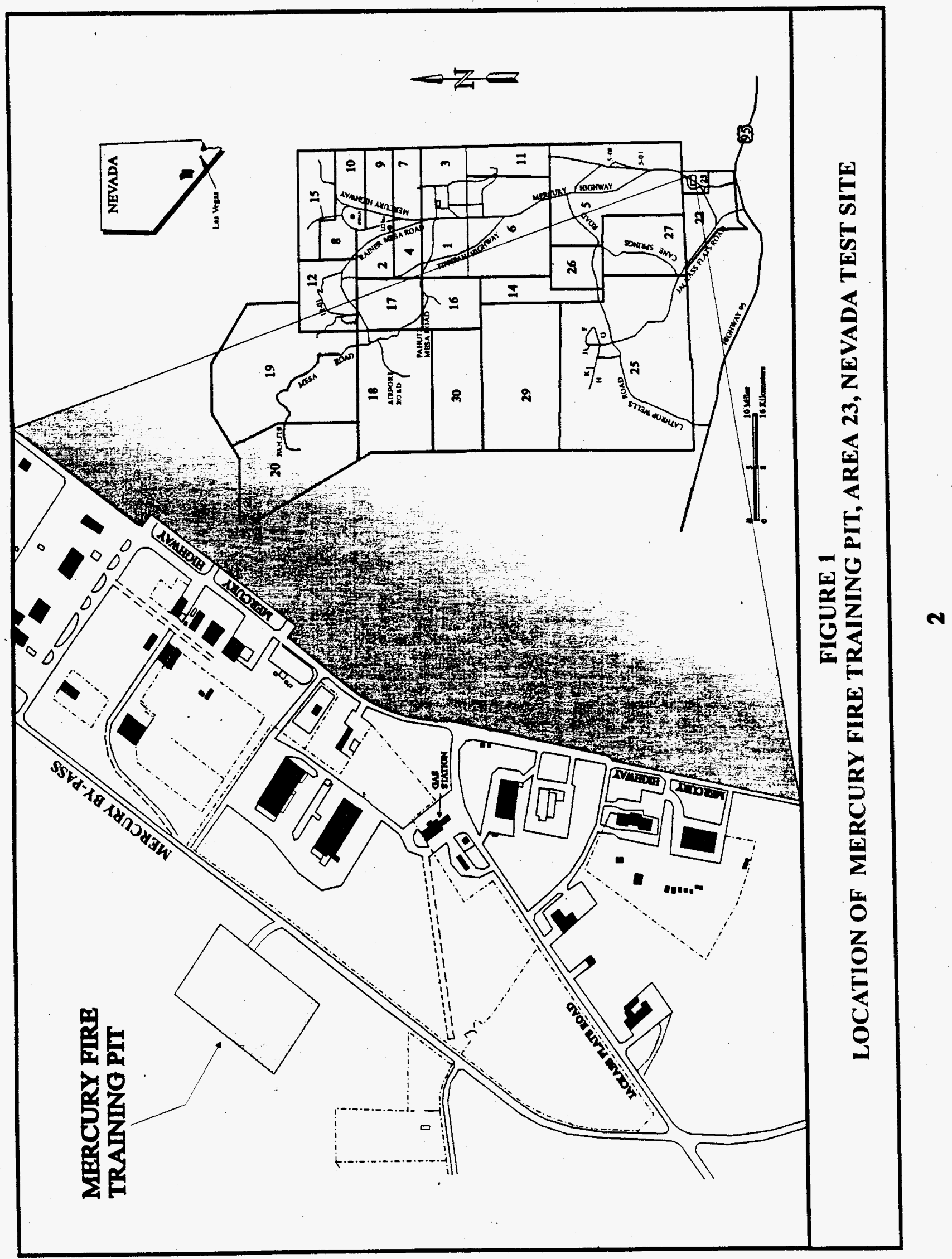




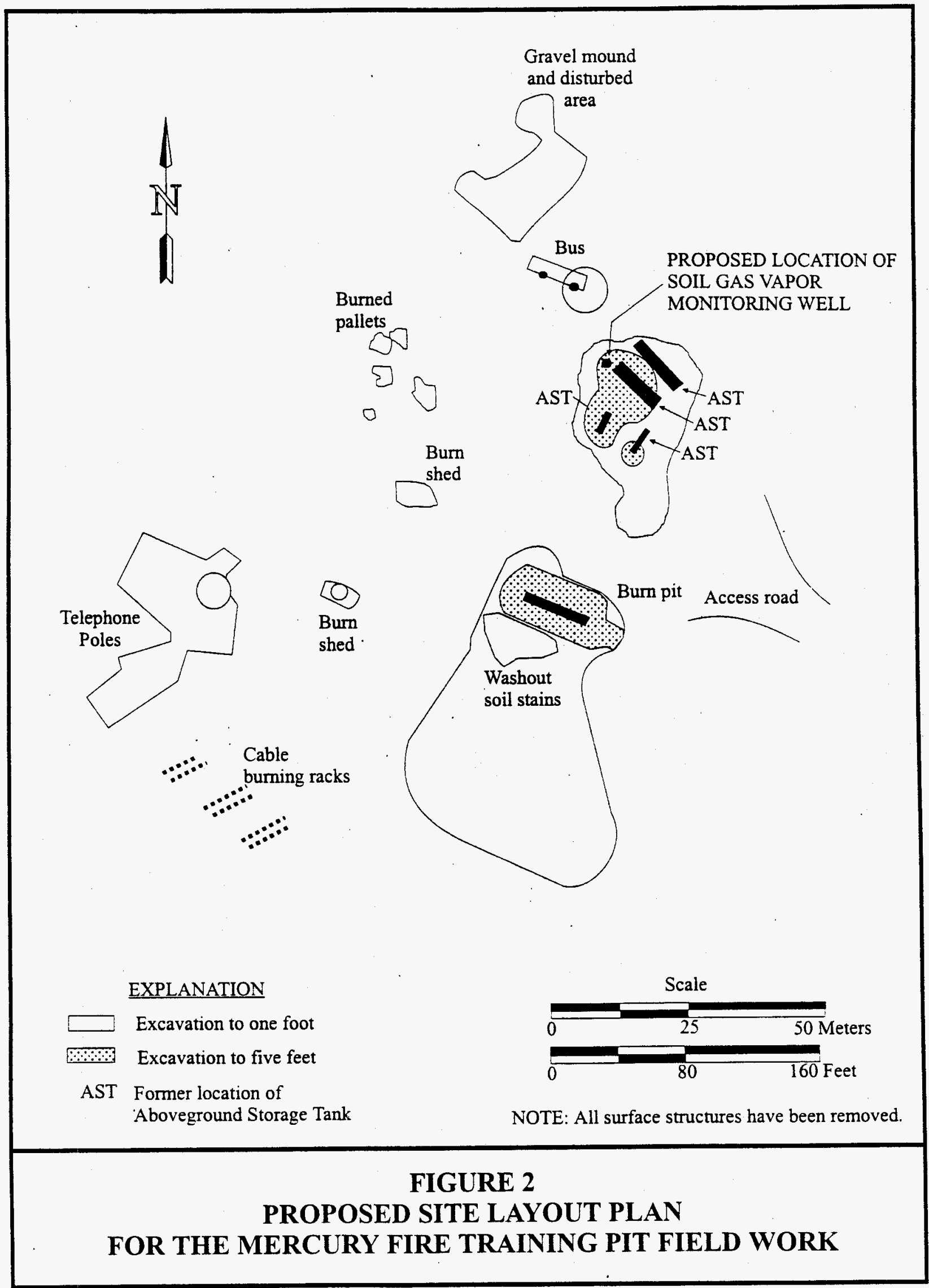


Soil sample results concluded the following:

- In the AST area, diesel, gasoline, and unknown petroleum hydrocarbons were found in concentrations greater than the Nevada Division of Environmental Protection (NDEP) action level of 100 milligrams per kilogram $(\mathrm{mg} / \mathrm{kg}$ ) of total petroleum hydrocarbons. The impacted soil was found in shallow soils downslope of the ASTs and at greater depths immediately beneath the ASTs. The maximum length, width, and depth of impacted soil was reported to be $40 \mathrm{~m}(130 \mathrm{ft})$ by $24 \mathrm{~m}(80 \mathrm{ft})$ by $15 \mathrm{~m}(50 \mathrm{ft})$, respectively. The maximum petroleum hydrocarbon concentration was $18,000 \mathrm{mg} / \mathrm{kg}$ diesel at a depth of $7.6 \mathrm{~m}(25 \mathrm{ft})$ below ground surface. The maximum concentration of

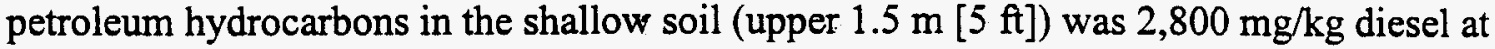
$1.2 \mathrm{~m}(4 \mathrm{ft})$ below ground surface.

- In the burn pit area, diesel, gasoline, and unknown petroleum hydrocarbons were found in concentrations greater than the NDEP Action Level. The impacted soil was found near surface downslope of the burn pit and at greater depths immediately beneath the burn pit area enclosed by the berm. Within the bermed area, the maximum length, width, and depth of impacted soil was reported to be $20 \mathrm{~m} .(65 \mathrm{ft})$ by $8 \mathrm{~m}(27 \mathrm{ft})$ by $9 \mathrm{~m}(30 \mathrm{ft})$, respectively. Maximum petroleum hydrocarbon concentrations were $10,000 \mathrm{mg} / \mathrm{kg}$ diesel at $6 \mathrm{~m}(20 \mathrm{ft})$ below ground surface, and $10,000 \mathrm{mg} / \mathrm{kg}$ of unknown petroleum hydrocarbon at $3 \mathrm{~m}(10 \mathrm{ft})$ below ground surface. Downslope of the burn pit, impacted

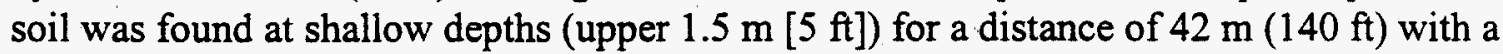
maximum width of $56 \mathrm{~m}$ (184 ft), indicating that the fuel may have breached or overflowed the berm and spread out on the gentle slope. The maximum concentration of petroleum hydrocarbons in the shallow soil was $4,100 \mathrm{mg} / \mathrm{kg}$ of diesel at $0.3 \mathrm{~m}(1 \mathrm{ft})$ below ground surface.

- Total petroleum hydrocarbon concentrations greater than the NDEP action level were also found in three small areas associated with the overturned bus, the telephone pole storage area, and a burn shed. The maximum petroleum hydrocarbon concentrations at these sites were $1,400 \mathrm{mg} / \mathrm{kg}$ of waste oil, $440 \mathrm{mg} / \mathrm{kg}$ of an unknown hydrocarbon, and 130 $\mathrm{mg} / \mathrm{kg}$ of an unknown hydrocarbon, respectively. All concentrations were identified at a depth of $0.3 \mathrm{~m}[1 \mathrm{ft}])$, but at different locations.

- Xylene was detected in four subsurface soil samples from the AST area. The sample with the greatest xylene concentration $(480 \mathrm{mg} / \mathrm{kg}$ ) exceeded the U.S. Environmental Protection Agency's Region IX Preliminary Remediation Goal of $320 \mathrm{mg} / \mathrm{kg}$. The sample had a petroleum hydrocarbon concentration of $18,000 \mathrm{mg} / \mathrm{kg}$ of diesel. 


\subsection{PURPOSE}

The purpose of this Corrective Action Plan is to provide the strategy and methodology to close the Mercury Fire Training Pit. The strategy and methodology are based upon the site characterization results and the results of the risk evaluation provided in the CADD (DOE, 1999).

\subsection{SCOPE}

The preferred corrective action alternative, as detailed in the CADD (DOE, 1999), includes closure in place with partial excavation, disposal, administrative controls, and post-closure monitoring. The scope of the corrective action alternative consists of the following activities:

- Preplanning and site preparation, including the preparation of all plans and permits, approval of a source of borrow material, delineating excavation boundaries, and mobilization of equipment to the site.

- Excavation of the impacted soil in the AST and burn pit areas to a depth of $1.5 \mathrm{~m}(5 \mathrm{ft})$ below ground surface.

- Excavation of the impacted surface soil downgradient of the AST and burn pit areas to a depth of $0.3 \mathrm{~m}(1 \mathrm{ft})$ below ground surface.

- Disposal of excavated materials following applicable federal, state, and DOE regulations following Section 2.3 of this Corrective Action Plan.

- Backfilling of the excavated areas with clean borrow soil.

- Grading of the site to prevent ponding and promote surface drainage.

- Restricting access to the site by installing fencing and signs around the site and by enacting use restrictions.

- Installation of a soil gas vapor monitoring well. 


\subsection{CORRECTIVE ACTION PLAN CONTENTS}

This document is divided into the following sections in accordance with the approved FFACO Corrective Action Plan outline:

- Section 1.0 - Introduction

- $\quad$ Section 2.0 - Detailed Statement of Work

- $\quad$ Section 3.0 - Schedule

- $\quad$ Section 4.0 - Post-Closure Care

- $\quad$ Section 5.0 - References

The appendices of this document have been modified from the approved FFACO outline. The following FFACO outline appendices have not been included or revised as indicated below:

- $\quad$ Appendix A1: Engineering Specifications and Drawings This appendix is not warranted for the site as there are no construction or engineered cover requirements for closure.

- $\quad$ Appendix A2: Sampling and Analysis Plan

The sampling and analysis requirements for the site are detailed in Section 2.4 "Clean-up Verification," therefore, a separate sampling and analysis plan is not included as an appendix.

- $\quad$ Appendix A3: Project Organization This appendix is identified as Appendix B.

The appendices included in this document are provided as follows:

- Appendix A: Post-Closure Inspection Checklist

- Appendix B: Project Organization 


\subsection{DETAILED STATEMENT OF WORK}

\subsection{APPROVED ALTERNATIVE IMPLEMENTATION}

This section describes how the approved alternative will be implemented at the Mercury Fire Training Pit. The approved alternative includes closure in place with partial excavation, disposal, administrative controls, and post-closure monitoring. In addition to field activities, planning and site preparation are also required. Whereas this alternative does not provide for the clean closure of the site, it does provide for the removal of impacted surface and near surface soils. In addition, the approved alternative provides a barrier of clean soil as protection for human health and the environment. The evaluation of Nevada Administrative Code (NAC) 445A.227 (2)(a-k) (NAC, 1996) is provided in the CADD (DOE, 1999).

\subsubsection{Preplanning and Site Preparation}

Prior to beginning excavation activities, the following planning and preparation activities must be accomplished:

- Preparation of planning documents such as the Site-Specific Health and Safety Plan (SSHASP), and the Field Management Plan.

- Site preparation including utility clearance, work permits, and delineation of excavation boundaries.

- Identification and approval of a source of borrow material, a source for water for dust suppression, and other construction activities.

- Scheduling and coordination of work with construction and waste management.

Completion of a readiness review to determine if all planning and prefield activities have been accomplished.

\subsubsection{Site-Specific Health and Safety Plan/Hazard Analysis}

A SSHASP, Hazard Analysis (HA), and Preliminary Hazard Analysis (PHA) will be prepared. A copy of the document will be kept on file in the Bechtel Nevada (BN) Environmental Restoration and the BN Environmental, Safety, and Health Division offices in Mercury, Nevada. The original document will be kept by the site supervisor at the work site. The SSHASP, HA, and PHA will be available on-site for review and signature by all workers prior to beginning work at the site. The SSHASP will provide a detailed, job-specific plan covering protection 
work at the site. The SSHASP will provide a detailed, job-specific plan covering protection against accidents or exposure of workers to waste. It will also discuss weather/air monitoring, accident reporting, emergency procedures, and physical and environmental hazards. The work will also be performed following the U.S. Department of Energy, Nevada Operations Office (DOE/NV) Nevada Environmental Restoration Project Health and Safety Plan (DOE, 1998b) and the BN Environment, Safety, and Health Manual (BN, 1999). In addition, the Material Safety Data Sheets file will be maintained by the Health and Safety Officer and will also be available on-site.

\subsubsection{Field Management Plan}

A Field Management Plan will be prepared for the closure activities. The plan will outline how the work will be accomplished and provide a detailed schedule for the project. In addition, it will identify the responsible parties for each aspect of the project and determine how decisions will be made. A copy of the Field Management Plan will be placed on file at the BN Environmental Restoration Office in Mercury, Nevada, and a copy will also be available at the project field site.

\subsubsection{National Environmental Policy Act Documentation}

A National Environmental Policy Act checklist, and any subsequent documentation, will be completed prior to beginning any excavation activities at the site. If necessary, a follow-up survey will be performed and will report on the condition of existing trees, shrubs, grassed areas, cultural resources, sacred sites, and wildlife immediately adjacent to the area which may be affected by construction activities, equipment and material storage areas, and access routes. Based on the findings of this survey, the excavation activities at the Mercury Fire Training Pit will follow all applicable federal, state, and local laws, regulations, and permits for protection of the environment. Off-road use of vehicles is not permitted.

\subsubsection{Field Activities}

\subsubsection{Excavation of the Impacted Soil}

In the immediate AST and burn pit areas, impacted soil will be excavated to a depth of $1.5 \mathrm{~m}$ $(5 \mathrm{ft})$ below ground surface. Impacted soil downgradient of these areas, and in three smaller areas associated with the overturned bus, the burn shed, and the telephone pole storage area, will be excavated to a depth of $0.3 \mathrm{~m}(1 \mathrm{ft})$ (Figure 2). The excavated soil will be transported to the Area 6 Hydrocarbon Landfill for disposal.

Based on conclusions presented in the CADD (DOE, 1999), removal of soil within the 0.3-m (1-ft) deep excavation boundaries, as shown in Figure 2, is expected to remove all impacted soil that exceeds $100 \mathrm{mg} / \mathrm{kg}$ petroleum hydrocarbon and is present at the surface and near surface. If 
impacted soil is found or suspected at shallow depths outside of these excavation boundaries based on field observations and monitoring, then that soil will also be excavated for disposal. For the 1.5-m (5-ft) deep excavation boundaries, delineated in Figure 2, impacted soil has been identified to extend to depths greater than the $1.5-\mathrm{m}(5-\mathrm{ft})$ excavation limit. However, removal of the upper $1.5 \mathrm{~m}(5 \mathrm{ft})$ of soil will provide a substantial boundary of protection from exposure to impacted soil.

\subsubsection{Decontamination of Equipment}

Excavation and drilling equipment will be decontaminated at the end of the project. The backhoe bucket and drilling augers will be decontaminated using Alconox ${ }^{\circledR}$ and water. Rinsate will be collected over the impacted soil so that rinsate will be disposed with the soil. Because soil samples will not be collected, decontamination of sample equipment will not be required. Trailers used to transport impacted soil to the landfill will be decontaminated only if visible residue remains in the trailer. If necessary, trailers will be decontaminated by scraping or using a high-pressure washer.

\subsubsection{Backfilling of Excavated Areas}

The excavations will be backfilled with clean borrow soil. If necessary, the clean material will be stockpiled until excavation in an area is complete and backfilling begins. The loader/backhoe will distribute and spread the borrow material into the excavations in lifts of approximately $0.2 \mathrm{~m}$ ( 8 in). The lifts will be compacted by several passes of the loader/backhoe. In excavations too deep and/or too restricted for the loader/backhoe to enter for compaction, the lifts will be compacted by downward blows of the backhoe bucket.

\subsubsection{Grading of Site}

The backfilled areas will be leveled to existing grade with the loader/backhoe to minimize surface obstructions and ponding.

\subsubsection{Installation of Soil Gas Vapor Monitoring Well}

A single soil gas vapor monitoring well will be installed near the edge of the impacted soil in the area of the former ASTs. The proposed location of the well is provided in Figure 2.

Assumptions for the well design were provided in the CADD (DOE, 1999). The assumptions state that a $6-\mathrm{m}(20-\mathrm{ft})$ deep monitoring well will be installed using a $17.15-\mathrm{cm}(6.75-\mathrm{in})$ diameter hollow stem auger. The well will be constructed of 5-cm- (2-in-) diameter, Schedule 40 polyvinyl chloride (PVC) casing with $0.05-\mathrm{cm}(0.020$-in) slotting and a locking well cap. Based 
on characterization data, the screened interval is expected to be located 4.5 to $6 \mathrm{~m}$ ( 15 to $20 \mathrm{ft}$ ) below ground surface. The exact depth of the screening interval will be determined at the time of installation based on field screening results of cuttings produced during installation. Number 2 graded sand packs will be placed around the casing from slightly below to slightly above the screened interval. A sodium bentonite grout seal will be placed below and above the screened interval and the upper portion will be capped with slightly expanding cement. Sand and sodium bentonite chips will be fed down the auger flights or placed with a tremie pipe to prevent bridging of the sand and even distribution of the bentonite. After placement of the bentonite chips, water will be poured down the hole to hydrate the chips. If any problems are noted with the hydration of the chips, a sodium bentonite slurry will be placed with a tremie pipe.

A small concrete well pad, approximately $0.6 \mathrm{~m} \mathrm{x} 0.6 \mathrm{~m} \mathrm{x} 10$ centimeters $(\mathrm{cm})(2 \mathrm{ft} \times 2 \mathrm{ft} \times$ 4 inches [in]) with a well cover will be constructed on top of the well for protection. This well design serves as an example of how the well may be constructed and an example diagram is provided in Figure 3.

Final well design will be based on field conditions and field screening results and may warrant a nested design with multiple screened intervals. The borehole will be logged by a geologist to help determine the best locations for the screened intervals. In the case of a nested design, as many as three sections of $2.5-\mathrm{cm}$ (1-in) diameter PVC casing will be used in a single borehole. The screened intervals of each section of casing would be at a different interval and the intervals sealed with bentonite grout. An example of a nested design is provided in Figure 3 . If a nested design is chosen, monitoring samples will be collected from each casing.

The monitoring well will be sampled biennially (every two years) for three sampling events, or a total of six years. Gas vapor samples will be field screened for the following:

- Oxygen, using an oxygen meter or multigas monitor.

- Carbon dioxide, using a dreager tube or carbon dioxide monitor.

- Methane, using a multigas monitor.

- Volatile organic compounds (VOCs), using a photoionizing detector.

Gas samples will also be sent to an analytical laboratory for VOCs and semivolatile organic compounds (SVOCs). Results of the monitoring will be provided in a biennial report. 


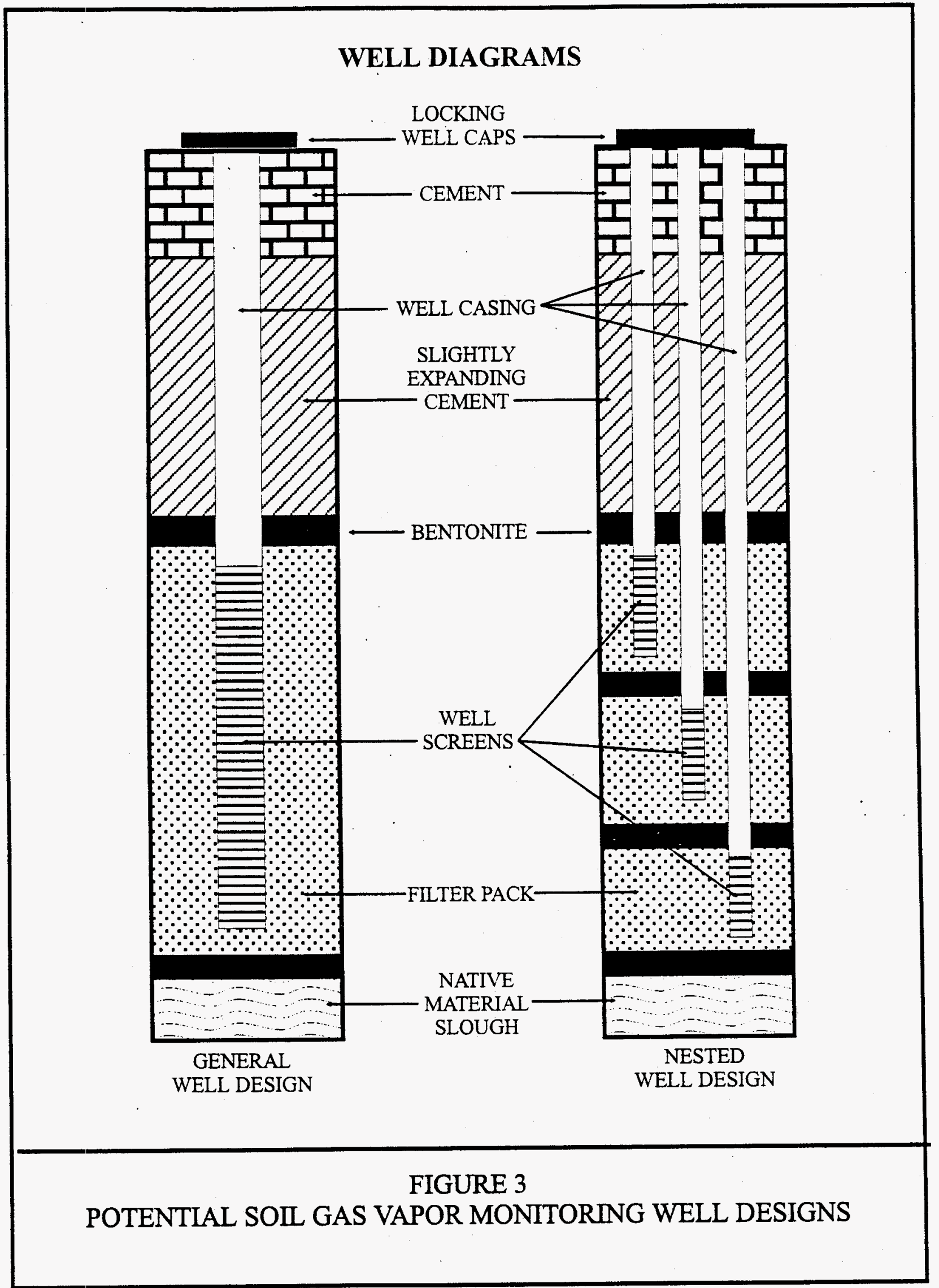


The data will be evaluated at the end of the six-year monitoring period to determine if natural attenuation rates are sufficient to degrade the remaining petroleum hydrocarbons to less than $100 \mathrm{mg} / \mathrm{kg}$ in 30 years.

Verification of degradation by natural attenuation can be demonstrated by a combination of the following:

- An increase over time of carbon dioxide, which is by-product of metabolic activity.

- A decrease over time of oxygen, which is a growth stimulant for microbes.

- An increase in the ratio of compounds that are difficult to degrade to compounds that are easily degradable, which is determined through VOC and SVOC analyses.

- The presence of metabolic intermediaries, which are simpler but incompletely degraded forms of the constituents of concern. This will also be determined through VOC and SVOC analyses.

Although these criteria are commonly used to demonstrate natural attenuation at sites impacted with petroleum hydrocarbons, site conditions may not be conducive to evidence of all four criteria. Therefore, final demonstration criteria will be determined as analytical results are received and evaluated.

\subsubsection{Restricting Access to Site}

A fence consisting of T-posts and two strands of wire already exists along the site perimeter as shown in Figure 2. Warning signs will be affixed to the fence approximately every $30 \mathrm{~m}$ (100 ft) with the following message: "Warning, underground petroleum hydrocarbon contamination. Contact Environmental Restoration (295-7946) before working in this area. FFACO CAU 342." In addition, a Land-Use Restriction Form will be filed.

\subsection{CONSTRUCTION QUALITY ASSURANCE/QUALITY CONTROL}

Construction activities primarily consist of excavation and earth moving. Permeability and compaction testing will not be necessary. As a result, no engineered or designed construction quality assurance/quality control is required. 


\subsection{WASTE MANAGEMENT}

Waste from the corrective action will be managed following Table 1. Based on the characterization data, the only waste to be generated during the corrective action will be petroleum hydrocarbon-impacted soil and sanitary waste. Waste will be handled in accordance with DOE Standard Operating Procedure ERD-05-210, "Management and Minimization of Nonhazardous Waste at the Nevada Test Site for the Nevada Environmental Restoration Project" (DOE, 1994).

\subsubsection{Waste Minimization}

For the duration of the project, site workers will adhere to the principles of the BN Waste Minimization and Pollution Prevention Program. Care will be taken to segregate waste from nonwaste materials if at all possible.

\subsection{CLEAN-UP VERIFICATION}

The purpose of the excavation and backfilling is to remove surface and near surface soils that have been impacted with petroleum hydrocarbons and provide a protective barrier between the environment and the remaining areas impacted with petroleum hydrocarbon. The evaluation of NAC 445A.227 (2)(a-k) (NAC, 1996) is provided in the CADD (DOE, 1999). Because petroleum hydrocarbons will be left in place below the depth of $1.5 \mathrm{~m}(5 \mathrm{ft})$, no verification samples will be collected.

\subsection{PERMITS}

The only permit required for this project is an Excavation and Trenching Permit. An approved Excavating and Trenching Permit will be obtained prior to any excavation. The permit contains a justification for the trenching operation and a checklist of pertinent organizations which must inspect the site so that the trenching will not impact utilities. A copy of this permit will be kept at the project site by the site supervisor. 
TABLE 1 - MANAGEMENT OF VARIOUS WASTE TYPES TO BE PRODUCED AT THE MERCURY FIRE TRAINING PIT

\begin{tabular}{|c|c|c|}
\hline MEDIA & WASTE TYPE & DECISION \\
\hline \multirow{2}{*}{ EXCAVATED SOIL } & $\begin{array}{l}\text { Petroleum hydrocarbon levels less than } \\
50 \mathrm{mg} / \mathrm{kg}\end{array}$ & Soil will be spread on the site or returned to excavated area. \\
\hline & $\begin{array}{l}\text { Petroleum hydrocarbon levels greater than } \\
50 \mathrm{mg} / \mathrm{kg}\end{array}$ & $\begin{array}{l}\text { Waste will be transported to and disposed at the Area } 6 \\
\text { Hydrocarbon Landfill. }\end{array}$ \\
\hline \multirow{2}{*}{$\begin{array}{c}\text { PERSONAL PROTECTIVE } \\
\text { EQUIPMENT ANI HOUSEHOLD- } \\
\text { TYPE WASTE }\end{array}$} & $\begin{array}{l}\text { Daily waste impacted with petroleum } \\
\text { hydrocarbon levels less than } 50 \mathrm{mg} / \mathrm{kg}\end{array}$ & $\begin{array}{l}\text { Waste will be managed as sanitary waste and transported to } \\
\text { a sanitary landfill for disposal. }\end{array}$ \\
\hline & $\begin{array}{l}\text { Daily waste impacted with petroleum } \\
\text { hydrocarbon levels greater than } 50 \mathrm{mg} / \mathrm{kg}\end{array}$ & $\begin{array}{l}\text { Waste will be transported to and disposed at the Area } 6 \\
\text { Hydrocarbon Landfill. }\end{array}$ \\
\hline
\end{tabular}




\subsection{SCHEDULE}

\subsection{PROJECT SCHEDULE}

Because field activities are not anticipated to begin until Fiscal Year 2000, the final project schedule for the Mercury Fire Training Pit Corrective Action has not been determined at this time. Therefore, the schedule provided here is tentative. The schedule will require modifications if conditions exist that are outside the assumptions on which the schedule is developed. The DOE will keep the NDEP appraised of any conditions that may impact the project schedule. In the event that the project schedule requires modifications, the DOE will consult with NDEP personnel prior to initiating any changes.

\subsection{FIELD WORK CLOSURE SCHEDULE}

A tentative schedule for planned field work consists of the following:

- $\quad$ Preparation for Field Work

- Excavation Activities

- Well Installation

- Management and Disposal of Waste

- $\quad$ Securing the Site
October 1999

November-December 1999

December 1999

November-December 1999

December 1999

Field work will be done in the safest and most efficient manner possible. Sufficient flexibility has been placed in the project schedule to account for minor difficulties (weather, equipment breakdown, etc.). The schedule may require modification if conditions exist that are outside the assumptions on which the schedule was developed. 


\subsection{POST-CLOSURE PLAN}

The Post-Closure Plan for the Mercury Fire Training Pit consists of visual inspections and soil gas vapor monitoring.

\subsection{INSPECTIONS}

Inspections of the site will consist of visual inspections of the monitoring well, fence, and warning signs to see if they are in place and readable, and use restrictions are being followed. Inspections will be conducted biannually (six months). Additional, nonscheduled inspections may be required after severe weather events such as high winds. A copy of the post-closure inspection checklist is included in Appendix A.

\subsection{MONITORING}

As part of the closure activities, a soil gas vapor monitoring well will be installed on the edge of the above ground storage tank plume (Figure 2). Soil gas samples will be collected on a biennial basis and analyzed for VOCs and SVOCs. In addition, field screening will be done for oxygen, carbon dioxide, methane, and VOCs.

A biennial report will be prepared following each soil gas vapor monitoring episode. The biennial report will describe observations, modifications, and/or repairs and will include the following information: .

- Discussion of observations.

- Inspection checklist and maintenance record.

- Conclusions and recommendations.

A copy of each biennial report will be submitted to the NDEP. Sampling will continue for six years (three sampling events). If after six years the analytical results show that natural attenuation is decreasing petroleum hydrocarbon levels in the soil, monitoring will be discontinued. If levels are not shown to be decreasing after six years, a determination will be made by DOE/NV and NDEP as to how to proceed.

\subsection{MAINTENANCE AND REPAIRS}

Identified maintenance and repair requirements will be remedied within 90 days of discovery and documented in writing at the time of repair. The proposed biennial inspections will be performed for approximately six years after site closure, and will be documented on inspection forms. 


\subsection{REFERENCES}

BN, see Bechtel Nevada.

Bechtel Nevada, 1999, Environment, Safety, and Health Manual, Las Vegas, NV.

DOE, see U.S. Department of Energy.

FFACO, 1996, Agreed to by the Nevada Division of Environmental Protection, the

U.S. Department of Energy, and the U.S. Department of Defense.

NAC, see Nevada Administrative Code.

Nevada Administrative Code, 1996, NAC 445A, "Corrective Action," As adopted by the Nevada Environmental Commission, September, Carson City, NV.

U.S. Department of Energy, 1998a, Corrective Action Investigation Plan for CAU 342: Area 23 Mercury Eire Training Pit, Nevada Test Site, Nevada, DOE/NV--498, UC-700, Las Vegas, NV.

U.S. Department of Energy, 1998b, Environmental Restoration Project. Health and Safety Plan, Revision 3, Las Vegas, NV.

U.S. Department of Energy, 1999, Comective Action Decision Document for Corrective Action Unit 342: Area 342 Mercury Fire Training Pit. Nevada Test Site, Nevada, Revision 1, DOE/NV--534, Las Vegas, NV.

U.S. Department of Energy, September 1994, "Management and Minimization of Nonhazardous Waste at the Nevada Test Site for the Nevada Environmental Restoration Project," DOE Standard Operating Procedure ERD-05-210. 
Revision: 0

Date: 8/9/99

\section{APPENDIX A}

\section{POST-CLOSURE} INSPECTION CHECKLIST 


\section{AREA 23 MERCURY FIRE TRAINING PIT (CAU 342)} INSPECTION FORM

Inspect the well and surrounding area. Look for any unusual change in the unit such as accumulation of water, chemical odors, deterioration of structures, etc. Refer to the previous inspection of the unit in order to identify any changes. Inspections should be completed after a problem is reported by a contractor, DOE, NDEP, ER or other BN employees. Post Closure Care inspections will be done twice a year.

\section{GENERAL INFORMATION}

1. Date of inspection:

2. Facility Manager (name and organization):

3. Reason for inspection: Biannual: Problem Reported: Unusual weather:

Details (Name, organization and telephone number of person reporting problem):

4. Describe weather conditions over the past few weeks (high winds, precipitation, local flooding):

\section{MONITORING WELL AND GENERAL SITE CONDITION}

5. Condition of monitoring well and cover (cracked, tilted):

6. Condition of fencing (breaks, tilted, damaged):

7. Condition of signs (missing signs, fading, damaged):

8. Signs of erosion indicating runoff or runon (into) the area that could impact the monitoring well? No Yes If yes, explain: 


\section{AREA SURROUNDING WELL}

9. Describe any significant changes in the general area (within several hundred feet of the unit) from the previous inspection. Changes can include water in the area, change in land use, storage of materials nearby, soil piles, change in use of the facility, etc.

10. What is the (possible) effect of the change?

11. Other comments or observations:

12. Recommendations:

13. Does the finding(s) of this inspection require another inspection prior to the scheduled monthly inspection? No Yes If yes, date of next inspection:

Significant changes noted must be notified to the Project Manager and Task Manager upon return to the office.

Inspected by :

Signed:

Date:

Names of other persons on inspection (print): 


\section{APPENDIX B}

\section{PROJECT ORGANIZATION}


The following are the DOE/NV project contacts:

Runore C. Wycoff

Division Director

Environmental Restoration Division

U.S. Department of Energy, Nevada Operations Office

P.O. Box 98518

Las Vegas, NV 89193-8518

(702) 295-0250

Janet L. Appenzeller-Wing

Project Manager

Industrial Sites Project

U.S. Department of Energy, Nevada Operations Office

P.O. Box 98518

Las Vegas, NV 89193-8518

(702) 295-0461

The identification of the project Health and Safety Officer and the Quality Assurance Officer can be found in the appropriate DOE plan. However, personnel are subject to change and it is suggested that the Project Manager be contacted for further information. The Task Manager will be identified in the FFACO Biweekly Activity Report prior to the start of field activities. 


\section{NEVADA DIVISION OF ENVI RONMENTAL PROTECTION}

DOCUMENT REVIEW SHEET 


\section{DOCUMENT REVIEW SHEET}

Document Title/Number: Draft Corrective Action Plan (CAP) for Corrective Action Unit 342, Area 23

Mercury Fire Training Pit, Nevada Test Site, Nevada

Document Date: June, 1999

Revision Number: 0

Originator/Organization: Bechtel Nevada

Date Comments Due: July 23, 1999

Reviewer/Organization: Nevada Division of Environmental Protection - Reference letter from Michael

McKinnon to Runore Wycoff dated July 19, 1999.

\begin{tabular}{|c|c|c|c|c|}
\hline $\begin{array}{c}\text { Comment } \\
\text { Number/ } \\
\text { Location }\end{array}$ & Type" & Comment & Comment Response \\
\hline $\begin{array}{c}\text { 1. Page 12 } \\
\text { Paragraph } \\
\text { following bullets }\end{array}$ & & $\begin{array}{l}\text { All types of substitute criteria which may potentially } \\
\text { be considered in determining efficacy of the natural } \\
\text { attenuation should be indicated here. Also, "recieved" } \\
\text { should be "received". }\end{array}$ & $\begin{array}{l}\text { Text referencing potential use of alternate criteria } \\
\text { has been removed. If, at the time of biennial } \\
\text { sampling, it is determined that the data is not } \\
\text { appropriate, new criteria will be negotiatied with } \\
\text { the NDEP at that time. }\end{array}$ \\
\hline $\begin{array}{c}\text { 2.Page 14, } \\
\text { Table 1 }\end{array}$ & $\begin{array}{l}\text { The spelling correction was made. } \\
\text { PPE and household-type waste which is contaminated } \\
\text { to levels grater than } 50 \text { mg/kg (ppm). }\end{array}$ & Table entry was added. \\
\hline
\end{tabular}




\section{DISTRIBUTION LIST}

*Provide copy of initial distribution of Revision 0; remainder of list gets Revision 0 if approved without changes. The entire list receives Revision 1 , if issued.

\section{Nevada Department of Environmental Protection}

Paul Liebendorfer

Bureau of Federal Facilities

Division of Environmental Protection

333 W. Nye Lane, Room 13B

Carson City, NV 89706-0866

Mike McKinnon, Las Vegas Office

Bureau of Federal Facilities

Division of Environmental Protection

555 E. Washington, Suite 4300

Las Vegas, NV 89010-1043

\section{U.S. Department of Energy}

Janet Appenzeller-Wing

Environmental Restoration Division

U.S. Department of Energy, Nevada Operations Office

P.O. Box $98518 \mathrm{M} / \mathrm{S} 505$

Las Vegas, NV 89193-8518

Clayton Barrow

Environmental Restoration Division

U.S. Department of Energy, Nevada Operations Office

P.O. Box $98518 \mathrm{M} / \mathrm{S} 505$.

Las Vegas, NV 89193-8518

Sabrina Lawrence

1 (Controlled)*

Environmental Restoration Division

2 (Controlled)* $^{*}$

1 (Controlled)*

1 (Uncontrolled)*

1 (Uncontrolled)*

U.S. Department of Energy, Nevada Operations Office

P.O. Box $98518 \mathrm{M} / \mathrm{S} 505$

Las Vegas, NV 89193-8518 
DOE Public Reading Facility

P.O. Box $98521 \mathrm{M} / \mathrm{S}$ NLV040

Las Vegas, NV 89193-8521

DOE/Nevada Operations Office

Technical Information Resource Center

P.O. Box $98521 \mathrm{M} / \mathrm{S} 505$

Las Vegas, NV 89193-8521

U.S. Department of Energy

Office of Scientific and Technical Information

175 Oak Ridge Turnpike

P.O. Box 62

Oak Ridge, TN 37831-0062

\section{Bechtel Nevada}

Correspondence Control

Bechtel Nevada

P.O. Box $98521 \mathrm{M} / \mathrm{S}$ NLV008

Las Vegas, NV 89193-8521

David Cowser

Bechtel Nevada

P.O. Box $98521 \mathrm{M} / \mathrm{S}$ NLV082

Las Vegas, NV 89193-8521

Ann Heidema

Bechtel Nevada

P.O. Box 98521 M/S NLV022

Las Vegas, NV 89193-8521

Steve Nacht

Bechtel Nevada

P.O. Box $98521 \mathrm{M} / \mathrm{S}$ NTS306

Las Vegas, NV 89193-8521
1 (Controlled)

1 (Uncontrolled)

2 (Uncontrolled)

1 (Uncontrolled)*

1 (Uncontrolled)*

1 (Uncontrolled)

1 (Uncontrolled)* 


\section{DISTRIBUTION LIST (Continued)}

Curtis Obi

Bechtel Nevada

P.O. Box $98521 \mathrm{M} / \mathrm{S}$ NTS306

Las Vegas, NV 89193-8521

Shannon Parsons-DePry

Bechtel Nevada

P.O. Box 98521 M/S NTS306

Las Vegas, NV 89193-8521

Rick Remington

Bechtel Nevada

P.O. Box $98521 \mathrm{M} / \mathrm{S}$ NTS405

Las Vegas, NV 89193-8521

Craig Stowell

Bechtel Nevada

P.O. Box $98521 \mathrm{M} / \mathrm{S}$ NTS207

Las Vegas, NV 89193-8521

\section{IT Corporation}

Brad Jackson

IT Corporation

P.O. Box 93838

Las Vegas, NV 89193-8521

Rosa Silver

IT Corporation

P.O. Box 93838

Las Vegas, NV 89193-8521
- 1 (Uncontrolled)*

1 (Uncontrolled)*

1 (Uncontrolled)

1 (Uncontrolled)

2 (Controlled) 